\title{
Indigenous Cultural Practices and Natural Resources Conservation in Owerri, Imo State, Nigeria
}

\author{
Chris-Valentine Ogar Eneji \\ Dept. of Environmental Education, \\ University of Calabar, Nigeria \\ Charles Nnaji Ogundu \\ Department of Christian Religious Studies, \\ Faculty of Arts, University of Abuja, Nigeria \\ I. A. Ojelade \\ Dept. of Science and Environmental Education, \\ University of Abuja, Nigeria
}

\begin{abstract}
This study was designed to examine how indigenous socio-cultural practices contribute to the conservation and management of natural resources in Owerri, Imo state, Nigeria. The major purpose of this paper is to investigating the extent to which totemism (forbidden items), creation of protected areas (evil forest, sacred grooves, burial ground), shrines and sanctuaries as indigenous socio-cultural practices contribute to natural resources conservation in Owerri, Imo state, Nigeria. Three research questions and three commensurate null hypotheses were formulated for the study.. The population of the study consisted of farmers, carvers, traders, civil and public servants, conservation organizations among others. The multi-stage sampling techniques, was used to select a sample of 240 respondents from a population of about twelve thousand persons from 12 selected autonomous communities. A structured questionnaire divided into two sections with the modified four point Likert scale response option was the major instrument for data collection. The researcher with the help of trained community secretary administered the instruments and there was a $100 \%$ instrument return rate. Pie chart and simple percentage were used to answer the research questions, while Pearson Product Moment Correlation Analysis was used to test the relationship between the sub variables which makes up indigenous cultural practices and the conservation of natural resources at 0.05 significant levels at 238 degree of freedom. The result of the analyses of all the hypotheses were significant indicating that each of the sub-variable constituting indigenous cultural practices contributes to the conservation of natural resources in Owerri, Imo State, Nigeria. It was recommended among others that modern conservation activities should purposely design strategies to incorporate indigenous socio-cultural practices for the conservation of natural resources in the study area and beyond.
\end{abstract}

Keywords: indigenous, socio-cultural practices, totemism, evil forest and sacred groove conservation and natural resources

INTRODUCTION

Culture is a people's way of life which is unique to a particular group of people alone, this attributes shape their way of life in terms of food, music, religion, language spoken, their attire, kinship, marriage, festivals and dance among others. Culture also includes their belief system, practices and ceremonies and coronations. Natural resources are the stock on which any society depends on for their survival; these are all natural endowment given to any society by 
nature for their existence. Natural resources could come in form of forest and vegetation, landscape, mineral deposits, water bodies, sand dune, mountains and rocks, fertile agricultural lands, biodiversity species, land and rock formation, natural attractions etc that are given by nature free of charge.

Man's existence right from man's prehistoric times have left an indelible negative footmark on the environment and its resources vis a vis, the pattern of resources exploitation and the near absence of any worthwhile effort to conserve these resources for the need of the future generations. There has been a series of global concerns raised about the effort most conservation organizations have made so far in conserving environmental resources and the result they have achieved so far. It is a common sense that most conservation effort designed for the management of natural resources within the local communities has left more to be desired. Most scholars have attributed this near failure to the lack of commitment or near absence of the participation of the natural resources host communities right from the conception stage of the conservation projects to its implementation and the evaluation of such programs. This therefore calls to mind how any project could succeed without the active participation of the project host communities.

It has been observed that our socio-cultural practices have encouraged the conservation of natural resources. African culture can play some functional roles in the conservation and management of natural resources especially forest resources. Some cultural practices in the African Traditional settings like methods of worship, initiation rites, and the invocation of the sacred powers of the supreme beings, how these gods communicate their will to humans through the chief priests and how the gods are atoned if provoked can be harnessed to help in the conservation of natural resources. The major tenet of African socio-cultural practices are anchored on the ascription of supernatural powers to some aspect of the environment where man finds himself, this is because the gods lives amongst men, and their habitat must be preserve from human interference and disturbances. (Chikaire et al., 2012; Parrotta and Trosper, 2012; Mutasa , 2015).

Most African cultures forbid the exploitation and consumption of certain component of the environment. Where people believe that the gods or goddess lives, there is the total protection of the habitats of the gods from exploitation, utilization, entrance and agricultural activities, this can either intentionally or unintentionally propel the conservation of resources. Some African culture forbid the exploitation and consumption of certain species of biodiversity, these are termed totems, forbidden items or totemism. Some areas are majorly delineated for the worship of the gods of the land, these restricted areas are used for the worshiping of the gods, and these practices also contribute to the conservation and management of natural resources (Helvetas, 2011; Gaillard and Mercer, 2012; Eneji, et al, 2012). These African cultural strategies for natural resource conservation and management have somehow been eroded by acculturation and enculturation of most African cultures through the introduction of Christianity as a modern way of worship. There is therefore the urgent need to re-visit the principles of our African indigenous cultural/traditional and religious practices to assist in the conservation of natural resources, especially where modern conservation programs could integrate traditional knowledge systems into their activities in the conservation and management of our natural resources (Chikaire et al., 2012; Kala, 2012 Wasongo et al., 2011; Hilhorst, 2015).

This stems from the fact that since modern concerted efforts have refused to yield the desired result of conserving natural resources, it is therefore necessary that natural resources host communities should look inwards and see how they can develop mechanism or strategies to 
conserve their natural resources, one such approach to natural resources conservation could be through the encouragement of indigenous cultural practices like their religion, totemism or forbidden items, assignment of portion of the environment as abodes of the gods, the designation of evil forest and burial grounds, shrines, sacred ponds and sanctuaries among others and how these could contribute to the conservation of natural resources (IPCC, 2014; Bhagwat, Ormsby and Rutte, 2011).

In Appiah-Opoku (2007)'s opinion, nearly every local community in Africa and world over have developed different strategies for the consistent conservation and management of natural resources. Traditional African societies also observed environmental ethics that help in regulating their interactions with the natural world and their environment (Shastri et al., 2002; Adu-Gyamfi, 2011). For instance, it is observed that African cultural or traditional cultures are practices laden with environmental characteristics, features and symbolism; but the proponents and propagators of Christianity saw the cultural practices and their traditional belief systems, worship and practices as rather inimical to the growth, unity, peace and cohesion of our communities, whereas, this is exactly what the cultural practices of these African cultures of these local people stands for in every society or community (Appiah-Opoku, 2007; IPCC, 2014; Bhagwat, et al., 2011).

The pressure put on natural resources by human society has created more problems on the environment, the environmental quality and its resources. Man's existence on the planet earth has been tied to the abundance of natural resources which nature has freely given to humanity. The extent of exploitation is worrisome especially as it is done without commensurate management or conservation to keep the pace of exploitation and regeneration at equilibrium. In an attempt to feed man's teaming population, man has exploited these resources to a point of severe threat to the total annihilation of the biodiversity and other natural endowments. Not also forgetting the fact that most of these natural resources were formed and deposited on the environment well over millions of years ago. Natural resources as explained include forest, mineral deposit, marine (ocean, seas, rivers etc), scenic and other aesthetic resources (AduGyamfi, 2011; Elorm-Donkor, 2012).

It has been acknowledge in the findings of Eneji et al. (2009a) that deforestation and land use is a major problem facing the world, Nigeria and indeed the people of Owerri West. Having it in mind that most environmental resources, be it mineral resources, forest, water or other natural endowment are finite in supply and may be exhausted sometime soon. Their rate of regeneration has been far slower than their rates of exploitation. These effects are orchestrated by the activities of rural farmers, hunters, timber loggers and those of the multinationals on traditionally protected areas in the forest zones as a result of increasing pressure from the demands of hard wood, agricultural land, forest products and mineral deposits. It was further observed that indiscriminate land use including farming is a problem that forest within the area has to contend with. While illegal logging of trees and harvesting of non timber forest products (NTFPs) continues to be a major problem in forest reserves, much has been done to reduce this trend, but the pressure keeps growing (Adu-Gyamfi, 2011; Agyarko, 2013).

There is threat to wildlife populations in all reserves from hunting, grazing and the activities of local farmers. There is the wanton and indiscriminate exploitation and collection of other forest products, like bitter kola, (Garcinia kola), bush mango (Irvingia gabonensis), hot leaves, cane, camwood (Ptheracarpus soyauxii), kola nut, (Kola nitida or Kola accuminata) snails (Archachatina spp chewing sticks, poles and afang (Gnetum Africana), (Eneji et al., 2009a; Awuah-Nyamekye, 2014). Further observations also indicated that there are changes in land 
use policy, which have taken over the control of land and other natural resources management from the hands of local authorities. This control gave the ancestral right and authority of caring, protecting and managing forest resources, land, water, mineral deposits and other such resources located within such lands to the state. Corrupt elements of society have abused the main tenet of this Land Use Act of 1979. (Chikaire, et al., 2012). Furthermore, the creation of forest reserves and National Parks to protect forest and forestland for future generations has also removed control from traditional authorities leaving less forests land for the ever growing population.

Adu-Gyamfi, (2011) in his study found that in almost every traditional African setting or community, each community has what they revere or hold sacred either as the presence of their gods or their goddesses, or there is a very important symbolic reason attached to such objects in the course of their existence. In almost every community in Cross River, there is hardly any community that exists without a sacred groove, evil forest, sacred pond, evil stream, burial ground, or forbidden forest. Here some part of the environment are delineated for the worship of the gods and goddesses, (Bhagwat, et al, 2011; Dan- Ayaa and Waswa, 2016). Some aspects of the socio-cultural practices carried out in some communities include:

\section{Totemism or forbidden items:}

Totem, totemism, totemic or forbidden items: this is a system of belief in which humans are said to have kinship or a mystical relationship with a spirit-being, such as an animal or plant. The entity, or totem, is thought to interact with a given kin group or an individual and to serve as their emblem or symbol. The functions that totems serve in African society are scientific, not superstitious. They are symbols of unity and oneness among Africans. They help members of the same family identify, recognize and belong to each other even when they have never met before in their lives.

Right here in Nigeria, there are several communities that not only revere snakes, but also observe a tradition of not killing them. In such places, killing snakes often attracts very serious penalties such as human-like funeral rites for the killed snake. There are other places in Nigeria where killing a snake could land you in plenty of trouble. Some of these communities include: Nembe in Bayelsa: Dan-Ayaa and Waswa, (2016) found that it is forbidden to kill snakes in this Bayelsan community. Such actions could attract serious sanctions. This is also the tradition in Anambra (Idemili and Ukpor, Nnewi-South Local Government, it is forbidden to kill pythons and green snakes. Killing these creatures would lead the said snake killer to perform burial rites for the python. Interestingly enough, there has been no incidence of pythons killing by the villagers as they're merely shooed away when sighted by villagers.

Same culture of not killing snakes is also practiced in Imo state (Mgbidi, Oru West Local government area of Imo State,) killing of python is forbidden since it is seen as the gods of the community. Going against this time-tested tradition could lead to similar consequences as in Ukpor above. Other places where snakes are revered include Ebonyi (the Okposi community) and Ile-Alakpa, Ogbomosho, Oke Ogun in Oyo State and Nnewi in Anambra State. In communities like Umuaro, male deer (stag) are forbidden from being killed, while in Bekwarra, (Gakem) of Cross River state, the road runner (anyiribom) is not killed. Ancient legendry has it that during war, the bird follows the trail of Gakem people and wipes their footprint so that the enemies may be prevented from tracing their direction and attacking them (Helvetas, 2011; Gaillard and Mercer, 2012).

In Dan-Ayaa and Waswa, (2016) studies on indigenous knowledge and the conservation of natural resources in Teso District of Kenya, using interview, rapid rural appraisal and 
questionnaire, the author found that during the years preceding Kenya's independence, different clans and sub-clans within Teso District highly upheld totemism as a cultural practice of the people. The Teso community members had a complexity of varied ideas and ways of behavior based on the world view drawn from nature. The above in the views of Eneji et al., (2012) included ideological, emotional, reverent, and genealogical relationships of social groups or specific persons with animals or natural objects. Such animals and objects according to the Teso community members were viewed as companions, relative, protector, progenitor, or helper and were usually ascribed supernatural powers and abilities and were offered a combination of respect, veneration, awe and fear. Among the members of the Teso people of Busia County, (the African Mourning Dove, the Half-Collard Kingfisher, the Nubian Nightjar and the Barn Swallow) locally known as Akabulutu, Amuruon, Asulwenyi and Emelete, for instance were highly respected prior to Kenya's independence since such birds were treated as symbols for different clans and were also associated with good luck and wealth (Dan Ayaa and Waswa, 2016).

These authors further posited that in gratitude, none of the people of the Iteso heritage whose ancestors treated the above as totems could kill, hurt or eat such birds. Furthermore, there were certain tree species that were never felled due to some beliefs that such were associated with water sources, having medicinal properties, associated with bad omen, ancestor or were associated with luck and wealth. The fig tree locally known as Ebule for instance was associated with spirituality and where traditionally community members used to worship under could never be tampered with. Likewise, the Kigelia Africana tree locally known as Edodoi that was believed to be an effective cure for mumps where by the patient only needed to visit it very early in the morning (earlier than anybody else) and go rubbing the infected chicks around the plant several times, was never carelessly felled (Agyarko, 2013; AwuahNyamekye, 2014).

In the studies of Adu-Gyamfi, (2011) and Awuah-Nyamekye (2014) respectively, their findings contend that among most African indigenous communities, totemic objects and materials vary significantly over tribes and clans. They gave examples of totemic animals to include mere mammals (Leopards, Lions, Elephants, Monkeys, Buffalo), and birds such as the (Falcon, Raven, parrot) among others. Similarly, reptiles like turtles, crocodiles, snakes (python, viper and boa), scorpions, crabs and fishes were also mentioned as totemic species (Krech, 2005; Tonukari, 2007; Chacon, 2012).

\section{Sacred groves, shrines, sanctuaries}

Wadley and Colfer, (2004) found in their study that certain culturally defined and designated spots and territories were highly upheld by most community members as abodes of the gods and goddesses. These included burial sites, places for ceremonies such as swearing and oath taking, appeasing of evil spirits, cleansing of members infected by diseases considered contagious or members believed to have committed serious crimes such as murder and adultery, places inhabited by clan gods or spirits of once respected community elders and medicine men which were protected by respective clans. Others included evil forests, grounds for community cult initiations, ponds, sanctuaries, shrines among others (Tonukari, 2007; Rutte, 2011).

Rim-Rukeh, Irerhievwie and Agbozu, (2013) found that among some selected communities in Delta state, community members activities such as farming, grazing of animals or even settlements were prohibited from such protected areas. The Delta community members had various beliefs and practices related to both the dead and the living that had some links to the conservation of the environment (Wasongo, et al., 2011; Risiro, et al., 2013). 


\section{Mulching of farms:}

This is a system where farmers after tiling their mounds or heaps, plant their crops, yams and cover the top of the mound with fresh or dead leaves or grasses to reduce heat or temperature and removing moisture from the land. This process is also a latent process of reducing evaporation and direct sunlight heat to the top of the mounds where the yam seedling is planted. This practice is done during the dry season, especially during the harmattan and heavy sun heat (Rim-Rukeh, et al., 2013; Risiro, et al., 2013).

\section{Intercropping}

Intercropping is another method of boasting crop productivity and guaranteeing the success of any farm operations. Most root crops are intercropped with crops that grow above the ground to symbiotically relate with each other. The leaves of the crops on top of the soils are shed and worked like farmyard or compost manure to improve the soil fertility for the yield of the root crops. Yams and cassava are intercropped with maize, beans, okra, and many others. This outside improving the quality of soil fertility, they also help during crop pest, where some crop pest might be interested in a particular crop, once there is intercropping, these process guarantee the farmers from suffering from crop failure as a result of crop pest attack (Ogbuagu, 2011; Parrotta and Trosper, 2012; Mutasa, 2015).

\section{Hedgerow and Home garden}

Another is the planting of hedgerow and home garden. Hedgerow is trees planted as fence to separate one homestead from another and there are also used to separate one family land from another to avoid encroachment in to another's land. While home garden are gardens planted at home to serve some purposes. This produces some unintended and different effect from what the sole purpose of planting them in the first place. They shield the house from direct windstorm and rainstorm effects and now acts as windbreakers and carbon sink (Krech, 2005; Mutasa, 2015). Danquah, (2014) therefore found that the conservation of water courses, streams, water pans and wells as well as the associated vegetation was protected through rules that ensured their sustainability. More importantly were the shrines, caves and the water shed forests covering the springs which were never interfered with because of the belief that ancestors or evil spirits dwelt in such places (Bhagwat, et al., 2011). Again, reptiles such as snakes, frogs and toads that inhabited ponds, rivers and wells were protected from any harm due to the belief that they helped maintain / sustain the lives of these important water points. Also, the community members highly recognized and appreciated the importance of ponds, streams, springs and rivers as crucial sources of water for livestock and human beings as well as a source of fish. Therefore, in order to conserve these resources, there were strong rules and beliefs that protected such (Bhagwat, et al., 2011; Hilhorst, et al., 2015).

Other cultural practices include evil forest, sacred grooves, shrines, burial grounds and sacred ponds or streams. For example, in India, particular patches of forests are designated as sacred groves under customary law and are protected from any product extraction by the community. Such forests are very rich in biological diversity and harbour many endangered plant species including rare herbs and medicinal plants. Tiwari et al. (1998) cited in Tonukari, (2007) identified 79 sacred groves and their floristic survey revealed that these sacred groves are home to at least 514 species representing 340 genera and 131 families. About $1.3 \%$ of total sacred grove area was undisturbed, $42.1 \%$ had relatively dense forest, $26.3 \%$ had sparse canopy cover, and $30.3 \%$ had open forest. Notably, the species diversity indices were higher for the sacred grove than for the disturbed forest.

Rim-Rukeh, et al., (2013) study on two sacred groves, Oorani and Olagapuram, situated on the north-west of Pondicherry found a total of 169 angiosperms from both sites. The Oorani grove 
(3.2 ha) had 74 flowering plant species distributed in 71 genera and 41 families; 30 of them are woody species, 8 are lianas and 4 are parasites. The Olagapuram grove (2.8 ha) was more species-rich with 136 species in 121 genera of 58 families; woody species were fewer (21) while 9 lianas and 3 parasites occurred (Rim-Rukeh, et al, 2013). The traditional conservation of non human primates by Iban forest farmers in West Kalimantan, Indonesia, is an important part of their subsistence economy, and as such aided the promotion of certain aspects of the traditional Iban agroforestry system (Wadley and Colfer, 2004).

Danquah, (2014) observed that social taboos exist in invariably all cultures throughout the world, and represent a class of informal institutions, where social, cultural, traditional and religiously governed norms or taboo system define the human behavior. These taboos remain the prime factor guiding their conduct towards the exploitation of the natural resources. However, the singular role played by these informal systems of taboo in conservation of biodiversity has not been given its due importance. Researches have shown that the salient aspect of conservation borne out of the taboo system in practice surrounding the sacred natural sites, principally the sacred forests, ponds, shrine, sanctuaries and natural resources in some communities of Nigeria.

As noted previously, traditional natural resources management is shaped around local cultural practices, rules and regulations. These rules and regulations are most often enshrined in religious or cultural beliefs and superstitions and enforced by prohibitions. These have no legal backing, but the beliefs have been strong enough in the past to make people obey the regulations. In the context of natural resources management, they enhance biodiversity conservation and minimize the continuous use of natural resources, (Hilhorst, et al., 2015).

Risiro, et al., (2013) observed that most cultural practices if judged using the IUCN species classification into the IUCN red list into nine groups set through criteria such as rate of decline, population size, area of geographic distribution, and degree of population and distribution fragmentation. Confirming the position of the Holy Qur'an on conservation, some key chapters and verses supports the conservation of natural resources: Fitrah, Mizan and Tauhid, Khalifah, these portions identified specifically the role of man in resources conservation. In Sumatra, some management policies support the introduction of religious doctrines into land management policies, these areas are Al-Mawat, land regeneration plan, Harim for water resource protection, Himoar for sustainable resources management (Henshey, 2011).

Rutte, (2011) found that for Africans, there is no clear separation between what is secular and what is sacred. Everything and every act are looked upon in a religious and customary perspective. Africans view themselves as part of the environment. Man is conceivable only in this cosmic interweavement. This web of relationship is what makes Africans view the earth as their mother and themselves as her children. Little wonder, Africans refer to their land as mother earth. Despite the fact that humanity, nature and the gods are distinct concepts, they belong to some ontological categories that are interrelated and interdependent.

Therefore plants, animals, rock, water and other non-living things are part of nature, which is the product of creation deserving to be respected as much as human beings who are also part of nature. This is what makes Africans regard themselves as being in close relationship with the entire cosmos. This position of man being a constituent part of the environment and God's creation, it is expedient that man must protect the interest of other part of God's creations; this was confirmed by UNESCO, (2011).

Arising from this review therefore, this study seeks to answer the following questions: How does totemism contribute to the conservation of natural resources in Owerri in Imo State? 
How does the creation of protected areas (evil forest, sacred grooves burial grounds etc) contribute to the conservation of natural resources in Owerri, Imo state?

To what extent does sacred pond and shrines influence the conservation of natural resources? Three commensurate null hypotheses were also formulated and tested at 0.05 significant level thus:

- Totemism (forbidden items) as an a cultural practice does not significantly influence the conservation of natural resources in Owerri, Imo State.

- There is no significant relationship between protected areas (evil forest, sacred grooves, burial grounds etc) and the conservation of natural resources in Owerri, Imo state

- The creation of sacred pond and shrines does not significantly influence the conservation of natural resources in Owerri, Imo state.

\section{MATERIAL AND METHODS}

The research design adopted for this study is the expost facto and the survey inferential research design.

\section{Study area}

The study area is Owerri West Local Government Area of Imo State, Nigeria. Owerri is the capital city of Imo state and it is made up of three Local Government Areas viz Owerri Municipal, Owerri North and Owerri West. Owerri is located within Latitude $5^{\circ} 29^{\prime} 1^{\prime \prime} \mathrm{N}$ of the Equator and Longitude $7^{\circ} 01^{\prime}$ 59" E of the Greenwich Meridian. Owerri is bounded in the North by Ngor Okpala LGA, in the West by Ohaju Egbema, in the East by Aboh Mbaise and in the south by Mbaitoli and Ikeduru LGAs respectively. According to the 2006 National Population Census, Owerri has an estimated population of about 198,234, projected to 2018 using 2.5\% growth rate, the current population of Owerri is about 255, 638 persons. Owerri covers a landmass of approximately about 100 square kilometres ( 40 sq miles) in area.

The State is blessed with abundant natural resources; these include abundant mangrove and tropical rainforest, crude oil, lead, zinc, white clay, fine sand, limestone and natural gas in commercial quantities. The state also produces agricultural products such as palm produce, cocoa and rubber. The main staple crops are yam, cassava, cocoyam and maize. Learned professionals, entrepreneurs and seasoned artists also abound in the state. The population of this study consists mainly of farmers and other agro related workers including timber dealers, those who survive on the exploitation of non timber forest products, sand dealers, carvers, blacksmith, palm wine tappers, traditional medicine practitioners, traditional rulers, women and youth groups within the rural communities of Owerri. The total population of the study area is about twelve thousand, three hundred and twenty four $(12,324)$ persons selected from 12 autonomous communities in Owerri.

The sampling technique adopted for this study is the stage-wise random sampling technique, $\mathrm{A}$ total of 240 respondents were selected from the 12 selected autonomous communities for the study, this is made up of both male and female women. The selection was done based on the population available in the community during the respondent selection process. The instrument for data collection was a structured 25 item questionnaire divided into two major section, section A elicit information on respondent's socio-demographic variables, while section B elicits information on the variables under study to gather data on the role of totemism (forbidden items), evil forest, ponds and shrines, burial grounds on the conservation of natural resources in Owerri, with a four point likert scale response option. The administration of the instrument was done by the researchers with the assistance of identified and trained community secretaries in their respective communities; same was collected with a 
return rate of $100 \%$. The Pearson Product Moment Correlations analysis was used to test the hypotheses. Results are presented on tables and pie charts.

\section{RESULTS AND DISCUSSION}

Research Question 1: To what extent does totemism (forbidden items) contribute to the conservation of natural resources in Owerri? Figure 1 shows respondent's opinion on the extent to which totemism influences the conservation of natural resources in Owerri. Result presented on the pie chart (Fig. 1) shows that 52\% of the respondent, representing 126 persons posited that totemism as a cultural practice has a very high contribution to the conservation of natural resources in Owerri, Imo State, while 24\% (57) respondents ticked that totemism has a high contribution to natural resources conservation. $15 \%$ of the respondents (35 respondents) observed that totemism has a low contribution to natural resources conservation, while 22 respondents representing $9 \%$ hold that totemism has a very low contribution to natural resources conservation. A little further analysis shows that 183 respondents representing $76 \%$ holds that totemism contributes very high to the conservation of natural resources conservation, while a paltry 57 respondents $(24 \%)$ of the respondents holds that totemism has a low contribution to natural resources conservation in Owerri. Based on the result of this analysis, it therefore shows that $76 \%$ is far higher than the average, so totemism contributes very highly to environmental resources conservation in Owerri, Imo state.

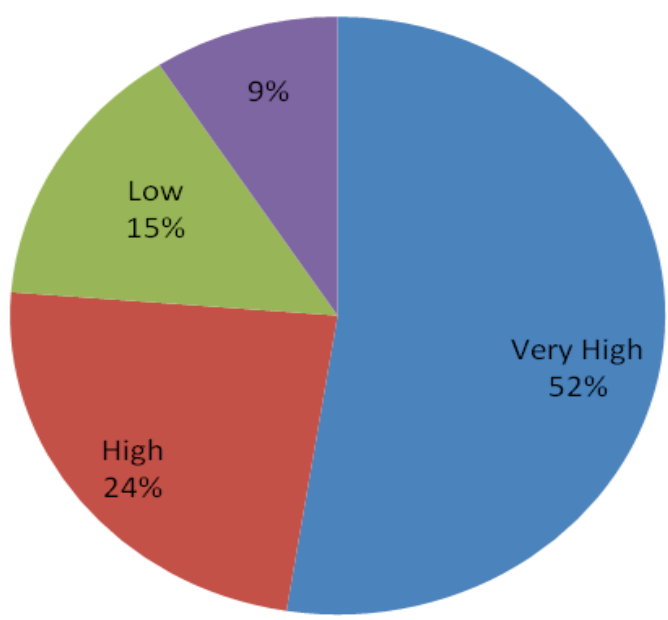

Fig. 1: Respondent's opinion on how indigenous cultural practices influnce conservation of natural resources in Owerri LGA

\section{Hypothesis One}

Totemism (forbidden items) as an indigenous cultural practice does not significantly contribute to the conservation of natural resources in Owerri, Imo State.

Table 1: Pearson Product Moment Correlation Analysis of the contribution of totemism to natural resources conservation in Owerri, $(\mathrm{N}=240)$

\begin{tabular}{lllll}
\hline Variables & $\sum \mathrm{X}$ & $\sum \mathrm{X}^{2} \Sigma^{\mathbf{Y}^{2}}$ & $\Sigma \mathbf{X Y}$ & r-val \\
\hline Totemism/forbidden item & 2099 & 3879 & \multirow{2}{*}{56453} & \multirow{2}{*}{0.67} \\
Conservation of natural resources & 1894 & 2585 & & \\
\hline
\end{tabular}

Significant 0.05 level, critical $r=0.178, \mathrm{df}=238$.

The result on Table 1 shows that the calculated $r$-value of 0.67 is higher than the critical $r$ value of 0.178 at 05 levels of significance and 238 degree of freedom. With this result, the null 
hypothesis which stated that Totemism (forbidden items) as an indigenous cultural practice does not significantly contribute to the conservation of natural resources in Owerri, Imo State is rejected, while the alternate hypothesis which stated that totemism (forbidden items) as an indigenous cultural practice does significantly contributes to the conservation of natural resources in Owerri is accepted, hence totemism (forbidden items) as an indigenous cultural practice does significantly contributes to the conservation of natural resources in Owerri, Imo State, Nigeria.

Research Question 2: How does the creation of protected areas (evil forest, sacred grooves burial grounds etc) contribute to the conservation of natural resources in Owerri, Imo state?

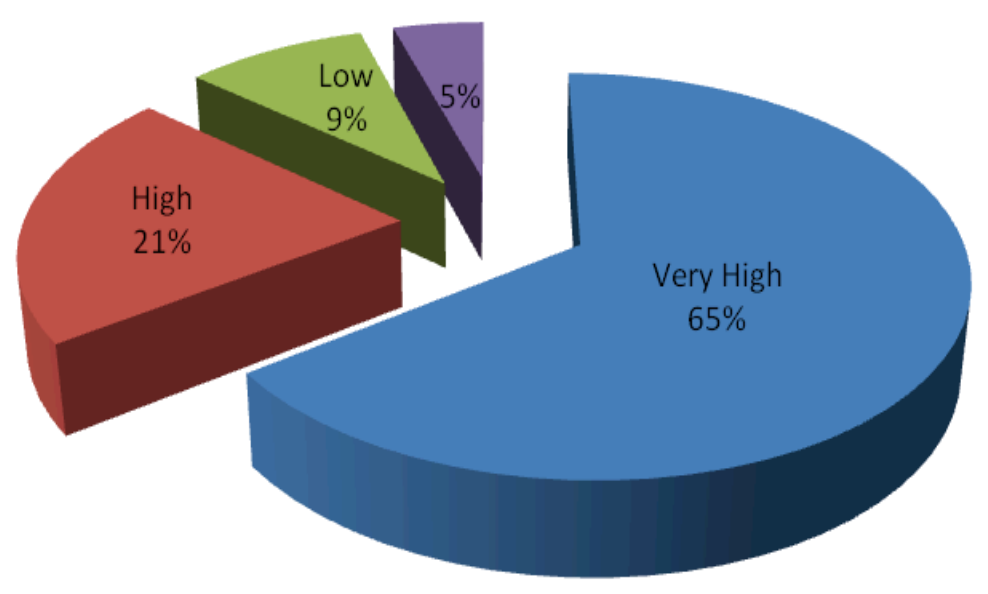

Fig 2: Respondent's opinion on the contribution ofEvil forest to the Conservation of Natural resources in Owerri LGA

Fig. 2 shows the result of pie chart analysis on how evil forest as an indigenous cultural practice contributes to the conservation of natural resources in Owerri, Imo State, Nigeria. 156 respondents, representing $65 \%$ indicated that creation of protected areas (evil forest, sacred grooves, burial grounds etc) as an indigenous cultural practices has a very high contribution to the conservation of natural resources, 51 respondents (21\%) ticked that evil forest as an indigenous cultural practices has a high contribution to the conservation of natural resources.

22 respondents, representing 9\% indicated that creation of protected areas as an indigenous cultural practices has a low contribution to natural resources conservation, while 11 respondents representing 5\% ticked that the creation of protected areas has a very low contribution to natural resources in Owerri. if those with high scores are summed up together, 207 respondents representing 86\% observed that the creation of protected areas as an indigenous cultural practice has a very high contribution to natural resources conservation, while 33 respondents representing 14\% ticked that the creation of protected areas as an indigenous cultural practice has a very low contribution to natural resources. Arising from this result, evil forest as an indigenous cultural practice has a very high contribution to natural resources conservation in Owerri.

\section{Hypothesis two}

There is no significant relationship between the creation of protected areas (evil forest, sacred grooves, burial grounds etc) and the conservation of natural resources in Owerri, Imo state. 
Table 2: Pearson Product Moment Correlation Analysis of no significant relationship between evil forest as an indigenous cultural practice and conservation of natural resources in Owerri

\begin{tabular}{|c|c|c|c|c|}
\hline \multicolumn{5}{|c|}{ LGA $(N=240)$} \\
\hline Variables & $\sum \mathrm{X}$ & $\sum \mathrm{Y}^{2}$ & $\sum X Y$ & r-val \\
\hline $\begin{array}{l}\text { Evil forest as an indigenous } \\
\text { cultural practice }\end{array}$ & 4051 & 3674 & & \\
\hline $\begin{array}{l}\text { Conservation of natural } \\
\text { resources }\end{array}$ & 2884 & 2598 & 56939 & 0.75 \\
\hline
\end{tabular}

Significant 0.05 level, critical $r=.178, \mathrm{df}=238$.

The result on Table 2 indicates that the calculated $r$-value of 0.75 is higher than the critical $r$ value 0.178 at 0.05 level of significance at 238 degrees of freedom. With this result, the null hypothesis which stated that there is no significant relationship between the creation of protected areas (evil forest, burial grounds, sacred groves etc) as an indigenous cultural practice and the conservation of natural resources in Owerri, Imo is rejected, while the alternate hypothesis which states that there is a significant relationship between the creation of protected areas (evil forest, sacred grooves, burial grounds etc) as an indigenous cultural practice and the conservation of natural resources in Owerri is accepted. This therefore means that there is a significant relationship between the creation of protected areas (evil forest, sacred grooves, burial grounds etc) as an indigenous cultural practice and the conservation of natural resources in Owerri.

Research Question 3: To what extent does sacred pond and shrines influence the conservation of natural resources? The analysis of data on respondent's opinion is as shown on Figure3

The result on Figure 3 shows the pie chart analysis of the extent to which sacred ponds and shrine can contributes to the conservation of natural resources in Owerri LGA. From the pie chart, the result shows that 145 respondents (60\%) ticked that sacred ponds and shrines has a high contribution to natural resources conservation, 49 respondents $(21 \%)$ ticked that sacred ponds and shrines highly contributes to the conservation of natural resources. 22 respondents (9\%) observed that sacred ponds and shrines have low contribution to natural resources conservation and 24 respondents (10\%) posited that sacred ponds and shrines have very low contribution to natural resources conservation in Owerri.

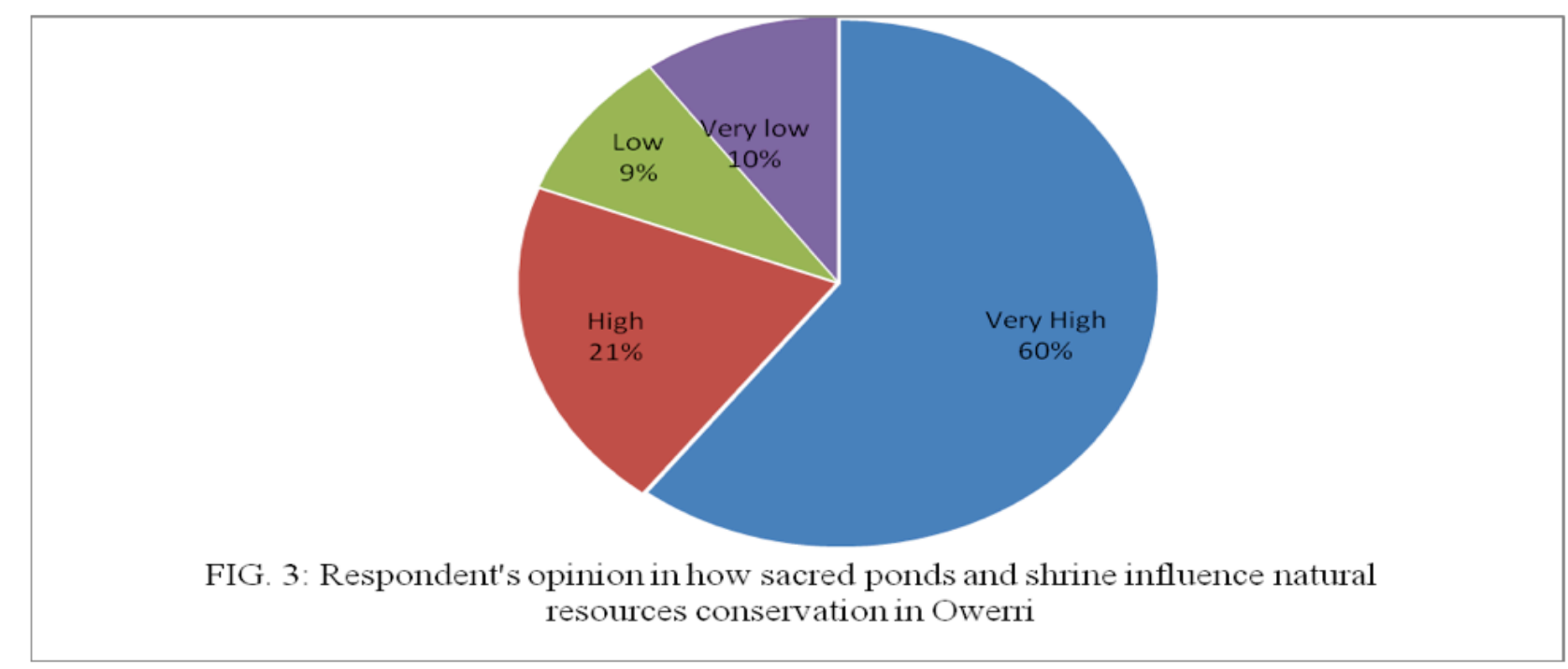

Further summation of the respondent's opinion shows that 194 respondents (81\%) ticked that sacred ponds and shrines have very high contribution to the conservation of natural resources, 
while 46 respondents (19\%) shows that sacred ponds and shrines have very low contribution to natural resources conservation. From this analysis therefore, it means that sacred ponds and shrines as indigenous cultural practices have very high contribution to natural resources conservation in Owerri.

\section{Hypothesis three}

The creation of sacred pond and shrines does not significantly influence the conservation of natural resources in Owerri, Imo state.

The result on Table 3 indicates that the calculated $r$-value of 0.77 is higher than the critical $r$ value 0.178 at 0.05 level of significance with 238 degrees of freedom. With this result, the null hypothesis which stated that there is no significant relationship between sacred pond and shrines and the conservation of natural resources in Owerri is rejected, while the alternate hypothesis which states that there is a significant relationship between sacred pond and shrines and the conservation of natural resources in Owerri is accepted. This therefore means that there is a significant relationship between sacred pond and shrines and the conservation of natural resources in Owerri.

\begin{tabular}{|c|c|c|c|c|}
\hline Variables & $\sum \mathrm{X}$ & $\sum \mathrm{Y}^{2}$ & $\sum X Y$ & r-val \\
\hline Sacred ponds and Shrines & 3987 & 2888 & \multirow{2}{*}{6752} & \multirow{2}{*}{0.77} \\
\hline Conservation of natural resources & 2341 & 2531 & & \\
\hline
\end{tabular}

Significant 0.05 level, critical $r=.178, \mathrm{df}=238$

The result of hypothesis one as shown on Table1 shows that the calculated r-value of 0.67 is higher than the critical r-value of 0.178 at 05 levels of significance and 238 degree of freedom, hence totemism (forbidden items) as an indigenous cultural practices does significantly contributes to the conservation of natural resources in Owerri, Imo State, Nigeria. This result is further buttressed by that shown on figure 1.When people restrict themselves from the exploitation and consumption of certain aspect of the environment and its resources, these species they do not exploit or eat increase in numbers naturally and the species become abundant in supply, hence a latent way of conserving these species that are totems. For example in Umuaro, the killing of the male deer is a totem, in Nnewi, the harming or killing of a pythongoes with a serious consequence, likewise in Ebonyi state where the green snake is revered so much. Since these species are not killed, they increase in abundance, hence their continuity and conservation.

This is in line with the earlier finding of Eneji, et al., (2009a, 2009b and 2012) who found at different points that public participation in biodiversity conservation is hampered by certain factors and because of the lack of information on the latent factors which helps in the conservation of biodiversity, people fear to participate or lack interest in participating in biodiversity conservation. In a similar vein, the authors also found that when forbidden items are many or when a specific specie that is becoming extinct in one place, but abundant in the area where they are totems, they help in the natural regeneration of those species, and would prevent global extinction. This is the case with the wild forest periwinkle. This is also in line with the earlier finding of Appiah-Opoku,(2007) who found similar result and concluded that when totem is made of certain species, such species are allowed to blossom in number and abundance, hence their conservation and sustainability. This result is not different from those of Chacon, (2012); Rim-Rukeh, et al., (2013); Awuah-Nyamekye, (2014). 
The result on Table 2 indicates that the calculated r-value of 0.75 is higher than the critical $r$ value 0.178 at 0.05 level of significance with 238 degrees of freedom. With this result, it therefore means that there is a significant relationship between evil forest as an indigenous cultural practice and the conservation of natural resources in Owerri. This result is further confirmed by the result on figure 2 on the pie chart. The implication of this result is anchored on the fact that when any area is designated as an evil forest, sacred groove or burial grounds, people are scared of going into such areas for fear of the spirit which is housed in the evil forest. This result also confirmed the earlier finding of Kala, (2012), who found that designated areas culturally meant for the protection of the abides of the gods are rich in biological diversities, hence a latent way of conserving these resources and the environment. It is a general belief that these protected areas are the abode of the god and goddesses, hence any unlawful passage, trespass or wandering into such a designated place has a serious effect on such a deviant.

Generally speaking, this result is a confirmation of the findings of Chacon, (2012); Henshey, (2011) who found respectively that all traditionally protected area are seen as the abode of the gods and goddesses, so entrance into such place is strictly prohibited, except by those who become committed to it, only initiates into such spiritual realms can be allowed to enter there. In most places, those who commit heinous offense like murder, adultery etc are banished and casted into such evil forest, where is it believed that the spirit will kill such person (s) while wandering in the evil forest. It is against the law for anybody to enter into such evil forest and exploit or harvest anything from the evil forest.

The result on Table 3 indicates that the calculated $r$-value of 0.77 is higher than the critical $r$ value 0.178 at 0.05 level of significance with 238 degree of freedom. With this result, it means there is a significant relationship between sacred pond and shrines and the conservation of natural resources in Owerri. Sacred ponds and shrines are also seen as abodes of the gods or community deities where they go to worship, sacrifice, appease or plead for favor from the gods or goddess. Often times, community members only go to such ponds, shrines and sanctuaries to consult the gods, this consultation, sacrifices, request or appeasement of the gods is normally done through the chief priest, who is the mouth piece of the gods, through whom they communicate their will.

The fear of the fact that the gods will visit their wrath on anybody who defaults or defiantly enter into such ponds, shrines or sanctuary to exploit or harvest species from such ponds, shrine and sanctuaries may die, or be punished by the spirit dwelling in such ponds, shrine or sanctuary. This result is in confirmation of the earlier results of Rim-Rukeh, et al., (2013), who found that specials areas are reserved by communities who hold the belief that the gods live within among men in special places, where they protect the communities. Such gods are consulted during famine, poor harvest, low rainfall, bareness or pestilence in the community. The chief priest is consulted to intercede on behalf of the people.

The desecration of such abodes of the gods, ponds, sanctuaries and shrines are visited with serious punishment. Most often, ponds are protected from unnecessary entrance by locating them in the wild, in the forest, river, or in the outskirt of the town, where entrance is regulated. Some species are also forbidden from being harvested and consumed like harvesting fishes or crab from the pond, woods, or other non timber forest products from the abode of such gods. This is in line with the finding of Chikaire, et al., (2012) who also found that the designation of environmental space and commensurate recognition that such space is an abode of the gods where every species found within that area is protected and conserved through the naked fear 
that the area is the abode of the gods, but latently these species are conserved and protected from exploitation and other form of human interference.

\section{CONCLUSION}

Arising from the result of data analyzed and the results from the analyses, this study conclude that indigenous cultural practices contributes a great deal to the conservation of natural resources in Owerri and other areas where indigenous cultural practices are still being practiced. Therefore, modern conservation agencies and other partners can use the strategies to conserve natural resources in our local communities. This conclusion is premised on the fact that a lot of literature has confirmed this postulation backed by the empirical data analyzed.

\section{RECOMMENDATION}

Based on the finding of this study, the following recommendations were made:

a. Modern conservation organization, agencies and partners should integrate indigenous cultural practices in their conservation effort.

b. Concerted effort should be made to encourage the reversion of people back to the embrace and practice of indigenous socio-cultural practices to conserve our pristine natural resources, especially those that their rates of regeneration has been found to be slower than the rates of exploitation.

c. Government and other policy makers should use traditional and indigenous knowledge system to develop programs for the conservation of environmental resources

d. Community where traditional or cultural practices of these sorts are still being practiced should be encouraged to preserve these cultures and promote them in other regions to enhance the conservation of natural resources.

\section{References}

Adu-Gyamfi, Y. (2011). Indigenous Beliefs and Practices in Ecosystem Conservation: Response of the Church. Scriptura 107:145- 155.

Agyarko, O.R., (2013). God of Life: Rethinking the Akan Christian Concept of God in the Light of the Ecological Crisis" The Ecumenical Review. Available at:

Appiah-Opoku, S., (2007). Indigenous beliefs and environmental stewardship: a rural Ghana experience. Indigenous Knowledge and Development Monitor 7(3):15-17

Awuah-Nyamekye, S., (2014). Managing the Environmental Crisis in Ghana: The role of African Traditional Religion and Culture with Special Reference to Berekum Traditional Area. United Kingdom: Cambridge Scholars Publishing.

Bhagwat S., Ormsby, A.A. and Rutte, C., (2011). The role of Religion in Linking Conservation and Development: Challenges and Opportunities. J. Study Religion Nat. Cult. 5(1):39-60.

Chacon, R., (2012). Conservation or Resource Maximization? Analyzing Subsistence Hunting Among the Achuar (Shiwiar) of Ecuador. In: The Ethics of Anthropology and Amerindian Research: Reporting on Environmental Degradation and Warfare. Eds., R. Chacon and R. Mandoza. New York: Springer. pp.311-360

Chikaire J, Osuagwu CO, Ihenacho RA, Oguegbuchulam MN, Ejiogu- Okereke N, Obi KU (2012). Indigenous knowledge system: The need for reform and the way forward. Glob. Adv. Res. J. Agric. Sci. 1(8):201-209.

Dan- Ayaa, D. and Waswa, F. (2016). Role of indigenous knowledge systems in the conservation of the bio-physical environment among the Teso community in Busia County-Kenya. African Journal of Environmental Science and Technology; 10(12): 467-475. DOI: 10.5897/AJEST2016.2182

Danquah, J.B., (2014). Akan Doctrine of God (194 Cb: A Fragment of Gold Coast Ethnics and Religion) UK: Routledge. doi:10.5539/enrr.v2n4p45 URL: http://dx.doi.org/10.5539/enrr.v2n4p45

Elorm-Donkor, L., (2012). African Worldview and Christian Pneumatology: Divergences and Convergence Didache: Faithful Teaching 12(1): 122-130.

Eneji, C. V. O., Gubo, Q., Jian, X., Oden, S. N., \& Okpiliya, F. I. (2009b). A Review of the Dynamics of Forest Resources Valuation and Community Livelihood: Issues, Arguments and concerns. Journal of Agriculture, biotechnology and ecology, 2(2), 210-231. 
Management in Cross River State, Nigeria. Environment and Natural Resources Research; 2(4): 45-53

Eneji, C. V. O., Gubo, Q., Okpiliya, F. I., Aniah, E. J., Eni, D. D., \& Afanghideh, D. (2009a). Problems of Public Participation on Biodiversity Conservation: the Nigerian Scenario. Journal of Impact Assessment and Project Appraisal, 27(4), 301-307. http://dx.doi.org/10.3152/146155109X479431

Eneji, C. V. O., Ntamu, G. U., Unwanade, C. C., Godwin, A. B., Bassey, J. E., Willaims, J. J \& Joseph, I., (2012).

Traditional African Religion in Natural Resources Conservation and

Eneji, C.V., Ntamu, G.U., Ajor, J.O., Ben, C.B., Bassey, J.E., Williams, J.J., (2012). Ethical Basis of African Traditional Religion and Socio cultural Practices in Natural Resources Conservation and Management in Cross River State, Nigeria. Journal of Research in Peace, Gender and Development; 2(2):034-043.

Gaillard, J.C. and Mercer, J., (2012). From knowledge to action: Bridging gaps in disaster risk reduction, Progr. Hum. Geogr. 37(1):93-114.

Helvetas, N., (2011). Nepal's Climate Change Policies and Plans: Local Communities' Perspective Environment and climate series 2011/1; Authors: Shiva Prasad Aryal and Bharat Pokharel; HELVETAS Swiss Inter-cooperation, Nepal.

Henshey, L . (2011). Religious \& Spiritual Mysteries Examiner. Environment and Natural Resources Research: 2(4): 159-172

Hilhorst, D., Baart, J., van der Haar, G. and Leeftink, F.M., (2015). Is disaster normal for indigenous people? Indigenous knowledge and coping practices. Disaster Prev. Manag. 24(4):506-522.

http://onlinelibrary.wiley.com/doi/10.1111/erev.12026/abstract

IPCC, (2014). Climate Change 2014: Impacts, Adaptation, and Vulnerability. Part A: Global and Sectoral Aspects. Contribution of Working Group II to the Fifth Assessment Report of the Intergovernmental Panel on Climate Change.

Kala, C.P., (2012). Traditional ecological knowledge and conservation of ethno-botanical species in the buffer zone of Pachmarhi Biosphere Reserve, Madhya Pradesh. Indian Institute of Forest Management, Bhopal, Madhya Pradesh. $194 \mathrm{p}$.

Krech, I. S., (2005). Reflections on Conservation, Sustainability, and Environmentalism in Indigenous North America. Am. Anthropol. 107(1):78-86

Mutasa, M., (2015). Knowledge apartheid in disaster management discourse: Is marrying indigenous and scientific knowledge the missing link? Jamba: Journal of Disaster Risk Studies 7(1): 123-138

Ogbuagu, B.C., (2011). We Who Are Strangers: Insights into How Diasporic Nigerians Experience Bereavement. Loss. J. Afr. Am. Stud; 16(2):300-320.

Parrotta, J.A. and Trosper, R.L. (2012). Traditional Forest-related Knowledge: Sustaining Communities, Ecosystems and Biocultural Diversity. London: Springer.

Rim-Rukeh, A, Irerhievwie, G and Agbozu, I. (2013). Traditional beliefs and conservation of natural resources: Evidences from selected communities in Delta State, Nigeria. International Journal of Biodiversity and Conservation; 5(7): 426-432, DOI: 10.5897/IJBC2013.0576

Risiro, J., Tshuma, T.D., Basikiti, A., (2013). Indigenous Knowledge Systems and Environment Management. A Case Study of Zaka District, Mansvingo Province, Zimbabwe. Int. J. Acad. Res. Prog. Educ. Dev; 2(1): 341-353.

Rutte, C., (2011). The Sacred Commons: Conflicts and Solutions of Resource Management in Sacred Natural Sites. Biol. Conser; 144(10):2387-2394.

Shastri, C.M., Bhat, D.M., Nagaraja, B.C., Murali, K.S. and Ravindranath, N.H., (2002). Tree species diversity in a village ecosystem in Uttara Kannada district in Western Ghats, Karnataka. Curr. Sci. 82:1080-1084

Tonukari, 0., (2007). Sacred Groves and Tree Worship among the Urhobos, Sapele, Eke Publishers, pp.45 - 47

United Nations Educational, Scientific and Cultural Organization (UNESCO) (2011). Osun Osogbo Sacred Grove, 13.09.2011, Available from http://whc.unesco.org/en/list/1118

Wadley, R.L., Colfer, C.J.P., (2004). Sacred forest, hunting, and conservation in West Kalimantan, Indonesia. Hum. Ecol. 32:313-338

Wasongo, V.O., Kambewa, D. and Bekalo, I., (2011). Community-Based Natural Resource Management (p. 194). In: W.O. Ochola, P.C. Sanginga, I. Bekalo (Eds.), Managing Natural Resources for Development in Africa. A Resource Book. Nairobi, Kenya: Univ. of Nairobi Press. 4:165-210. www.ccsenet.org/enrr 